\title{
壁近傍を上昇する水中気泡に働く低レイノルズ数域における揚力*
}

\author{
竹 村 文 男*1, 高木 周*2, 松本 洋一郎*2
}

\section{Lift Force on a Bubble Rising near a Wall in Water below Reynolds number of 20}

\author{
Fumio TAKEMURA*3, Shu TAKAGI and Yoichiro MATSUMOTO \\ ${ }^{* 3}$ Institute for Energy Vtilization Research, National Institute of Advanced Industrial Science and Technology, \\ 1-2 Namiki, Tsukuba-shi, Ibaraki, 305-8564 Japan
}

\begin{abstract}
Lift force on a spherical gas bubble rising near a wall in water was measured experimentally below Reynolds number $(R e)$ of 20 . We developed an experimental apparatus in which a CCD camera with a microscope follows the rising bubble. We used it to precisely measure the bubble radius, the rising speed and the distance between the bubble and the wall $(L)$ and then estimate the lift force for $R e<20$. We also proposed the equation for estimating the lift force by modifying the analytical solution obtained under the Oseen approximation and compared with the experimental results. The results reveal that the lift force can be expressed by the analytical solution for $\operatorname{Re}<1$. However, in the regime of $R e>1$, the experimental values are larger than the analytical values and the lift force should be expressed by a function of $R e$ and $L^{*}$. We also proposed a predicting equation for the lift force as a function of $R e$ and $L / R$ by fitting the experimental data.
\end{abstract}

Key Words : Bubble, Multi-Phase Flow, Viscous Flow, Lift Force, Wall Effect

\section{1. 緒論}

化学エネルギーを利用した熱エネルギー輸送システ ム，オゾンなどを用いた水質浄化技術において液相化 学反応が重要なテーマとなっている．液相反応におい ては, 反応ガスの溶解過程が反応律速となることが多 く,その溶解促進のために, サブミリオーダの気泡直 径をもつマイクロ気泡を活用することは，かくはん動 力を抑えるための省エネルギー技術として大きな意味 をもつ.

夜相反応における総括的な反応速度を予測するうえ で, 反応器内の流動解析は重要であるが, その中でも 壁近傍の気泡は，壁の存在により揚力を受けることか ら，気泡の挙動を把握するために揚力を定量的に評価 することは重要である. 特に, 水中の気泡は水の純度 により振る舞いが異なることから，その影響について の考察は重要である.

水中の気泡は超純水と呼ばれる非常にきれいな水中 では，界面で滑りのある状態，すなわち Fluid Sphere

* 原稿受付 2001 年 9 月 17 日.

*1 正員, 産業技術総合研究所(画 305-8564つくば市並木 1-2).

*2 正員, 東京大学大学院工学系研究科.

E-mail : takemura.f@aist.go.jp
として振る舞うが(1)(2)，界面活性剤など不純物が含ま れる水中では, 不純物を吸着して徐々に抵抗が増大 し(3) (6)，十分不純物が吸着した後には固体球と類似し た振る舞いを示す(7). 特に, Zhang らは(6) 界面活性剤 の濃度によっては固体球のように振る舞うまでの距離 が数 $\mathrm{m}$ にまで及ぶことがあることを報告している。 したがって, Fluid Sphere から固体球のように振る舞 いまでの遷移過程を含めて水中において壁近傍を上昇 する気泡の揚力を評価することは重要である。

壁近傍を壁面に平行に移動する粒子が受ける力に関 する解析には, Vasseur ら ${ }^{(8)}$, Cox ら ${ }^{(9)}$, MuLaugh. lin ${ }^{(10)}$, Cherukat ら(11)などがある。いずれの場合も 接合漸近展開法を用いて，壁近傍を上昇する粒子に働 く揚力および抗力の Oseen 近似レベルの解を計算し ている.Vasseur ら ${ }^{(8)}$ は，壁が十分遠くにあり，漸近 展開の外部領域に壁が存在する場合を, Cox ら ${ }^{(9)}$ は， 壁が内部領域にある場合を解析している。また， McLaughlin ${ }^{(10)}$, Cherukat ら(11) は，せん断のある流 れに対して, Vasseur ら (8) と Cox ら ${ }^{(9)}$ の解析をより 一般化し, 解析結果の適用範囲の拡張を行っている.

実験による固体球の壁近傍の揚力測定はV Vasseur $ら^{(8)}$ が, $R e$ 数が 0.1 程度の低い領域において行って いる．彼らは，2枚の鉛直平板間を沈降する粒子に働 
く揚力を, 平板に垂直な方向の速度から求めており, 彼らの導いた理論解と良好な一致を示している.

著者の一人(3) は, 顕微鏡付きのカメラを移動させな がら, 静止流体中を上昇する気泡の上昇速度と気泡径 を同時に湘定する装置を考案し，水中を上昇するガス 気泡の抵抗係数を測定し，抵抗係数を $5 \%$ 以内の精度 で評価している，また，著者ら(12)(13) はこの装置を応 用し, シリコンオイル中, すなわち気液界面が滑り条 件となる場合の球形ガス気泡の壁近傍の上昇速度およ び揚力を测定した．さらに，壁近傍を上昇する気泡に 働く抵抗力と揚力を求めるために, Vasseur ら(8) の結 果を応用した式を提案し, 実験結果との比較から提案 式の適用性について論じている。

本研究では，この装置を用いて水中における球形気 泡の壁近傍の揚力を低・中レイノルズ領域 $(R e<20)$ において測定した．特に界面活性剤を十分加えること により，固体球として振る舞う気泡について検討し た．実験では，水中に板を挿入し壁を作り，その近傍 を上昇するガス気泡に顕微鏡付きのカメラを追従させ ながら撮影した.そして，その画像から測定した気泡 径, 上昇速度, 気泡と壁面距離の結果から, 気泡に働 く揚力を評価した。 また，Vasseur ら (8) が求めた揚力 と比較するとともに, $R e<20$ において適用可能な揚 力に対する簡便な相関式を提案した.

\section{2.おもな記号}

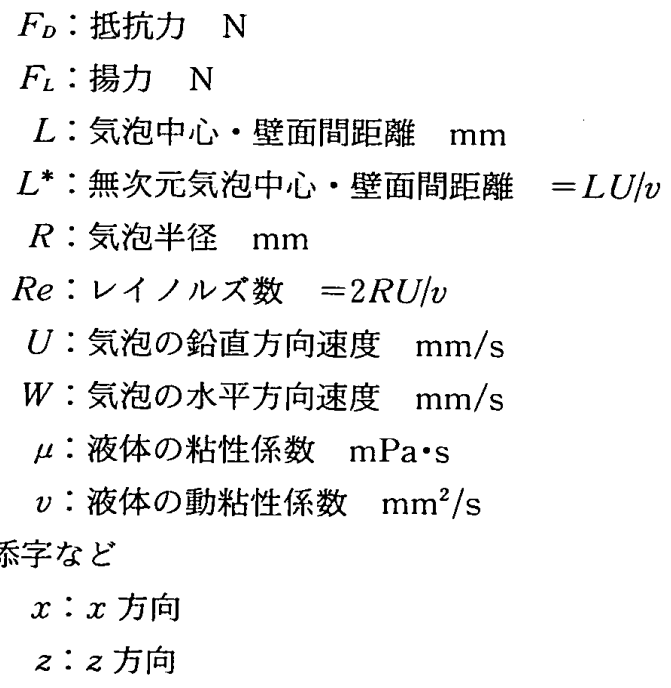

\section{3. 揚力 測 定 実 験}

図 1 に揚力測定実験装置を示す。本実験装置は，テ ストセクション, 気泡発生部, ステンレスプレートと, 顕微鏡, $640 \times 480$ ピクセルの画素をもつ CCD カメラ, ビデオ装置などの測定系, 光学用 $z$ 軸ステージ, ステ ージコントローラ, ピデオ入出力用ボードおよびそれ

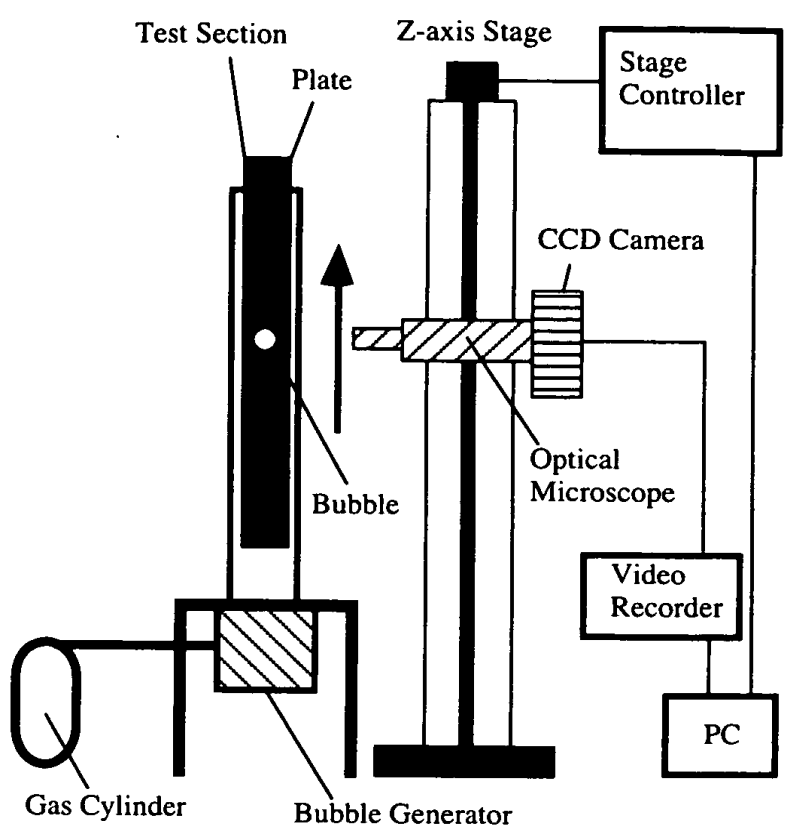

Fig. 1 Schematic of the experimental apparatus

らを制御するパーソナルコンピュータなどの制御系か らなる，実験装置，実験方法，実験デー夕整理方法に ついての詳細は文献 (12)，(13)に詳しく記載されてい ることから，ここでは省略するが，本実験では気泡径 が $0.2 \mathrm{~mm}$ 以下と小さいことから, 視野が約 1.6 $\mathrm{mm} \times 1.2 \mathrm{~mm}$ の高倍率のレンズを用い, 気泡径と気 泡中心・壁面間距離の測定精度向上を図った。

実験温度は $25.0^{\circ} \mathrm{C}$ でる。水は固体球と同様の振 る舞いをする気泡の揚力を測定するために, 超純水 (比抵抗值：18.2 M $\Omega$ )に約 $0.1 \mathrm{~mol} / \mathrm{m}^{3}$ のペンタノー ルを溶解させた水を用いた．ここで, $0.1 \mathrm{~mol} / \mathrm{m}^{3}$ と いう濃度について触れておく, Zhang ら ${ }^{(6)}$ は, 約 $0.75 \times 10^{-3} \mathrm{~mol} / \mathrm{m}^{3}$ Triton X-100 溶液を用いて気泡 の上昇速度変化を测定する実験を行い, 気泡が固体球 として振る舞うようになるまでの距離が約 $10 \mathrm{~cm}$ で ある結果を得ている. 本実験の界面活性剂の濃度は, 彼らの実験における濃度の 100 倍以上であること，お よびペンタノールの分子量が Triton X-100に比べ十 分小さいことから, 本実験での気泡が固体球へ遷移す るまでの距離は $10 \mathrm{~cm}$ より十分小さいことが予想で きる. 実際の測定においても固体球と同様の抵抗係数 となることを確認した。

また，水の粘性係数および動粘度は, ペンタノール の影響はまったくなく，それぞれ $0.9 \mathrm{mPa} \cdot \mathrm{s}, 0.9$ $\mathrm{mm}^{2} / \mathrm{s}$ でった。測定した気泡径の範囲は約 $50 \sim 200 \mu \mathrm{m}, R e$ 数は約 $1 \sim 20$, 壁からの無次元距離 $L / R$ は 2.5〜10であり,この範囲では気泡は球形を保 つことを画像から確認した。 


\section{4. 揚力の評価}

本実験のように定常状態が仮定できる場合(13)には， 力の釣合いは模式的に図 2 のように表せる. 浮力は, 鉛直方向から少し傾いた方向に上昇する気泡に働く抵 抗力と揚力の合力と釣り合う．特に，揚力は抵抗力の $z$ 方向成分とほほ釣り合う.したがって, 実験的に求 まる $z$ 方向速度 $W$ から気泡の抵抗力が求まれば，そ れが求める揚力となる。

しかしながら，壁から遠ざかる気泡に働く抵抗力を 評価するためには，壁の影響を考慮する必要がある。 著者ら ${ }^{(12)(13)}$ は，壁近傍を上昇する滑り気泡に働く $x$, $z$ 方向の抵抗力を, Vasseur ら ${ }^{(8)}$ の結果を応用した式, すなわち壁からの影響をOseen 近似，それ以外の抵抗 を無限流体中での以下の Mei らの式(14)で評価したモ デルによって，低・中 Re 数域においても十分評価で きることを示している.

$$
F_{D}=4 \pi \mu R U h(R e)
$$

ただし，

$$
h(R e)=1+\left\{\frac{8}{R e}+\frac{1}{2}\left(1+\frac{3.315}{R e^{0.5}}\right)\right\}^{-1}
$$

ここでも，その手法を用いて $z$ 方向の抵抗力を評価 する．ただし，本実験では固体球のように振る舞う気 泡を取扱っていることから, 無限流体中の抵抗力は滑 り気泡の場合の式と異なり，固体球に適用可能な式を 用いる必要がある。ここでは，無限流体中の抵抗力を， $R e$ 数が $0.01 \sim 20$ の範囲で適用可能である以下の式 で評価した(7).

$$
F_{D \infty, z}=6 \pi \mu R U \alpha f(R e)
$$

ただし，

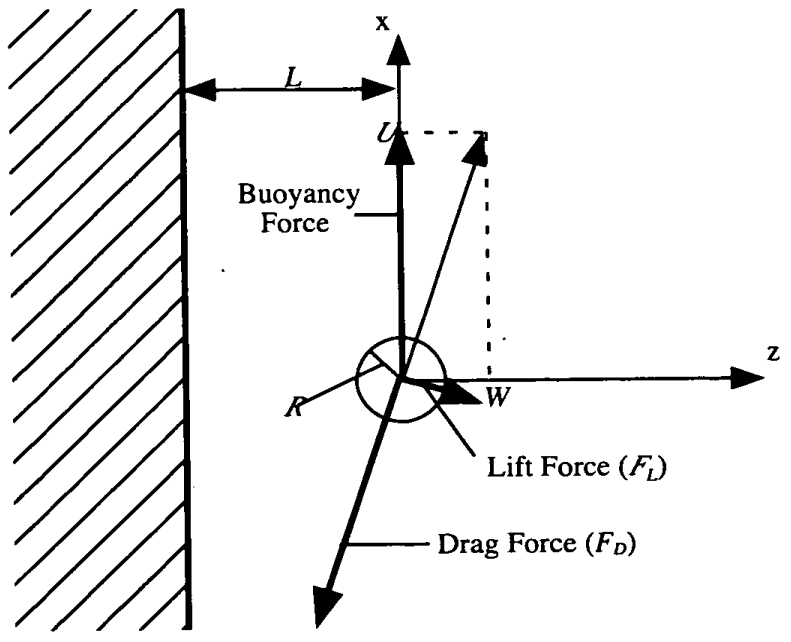

Fig. 2 Schematic of the force balace among buoyancy force, drag force and lift force

$$
\begin{gathered}
f(R e)=1+0.1315 R e^{\left(0.82-0.05 \log _{10} R e\right)} \\
(0.01<R e \leq 20)
\end{gathered}
$$

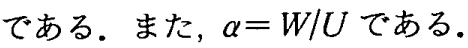

壁面に平行に移動する粒子に働く力を求める際に Vasseur ら ${ }^{(8)}$ が用いたOseen 近似では, 慣性項は $x$ 方向速度で定義される Re 数で展開している. 本実験 では，粒子は壁に平行ではなく，角度 $\alpha$ をもちな゙ら 移動する。したがって, Vasseur ら(8)の場合と異な り, $z$ 方向の慣性力も考慮する必要がある。しかし， $z$ 方向と $x$ 方向の速度比が実駼結果において最大 0.01 であることから， $z$ 方向の慣性力は $x$ 方向の慣性力に 比較して小さいとして， $z$ 方向に対して Stokes 近似 を行った。

以上から得られた式を用いて Vasseur ら ${ }^{(8)}$ と同様 に解を求めると, 以下の $z$ 方向の力の釣合い式が得ら れる.ただし，解の導出については文献 $(8)$ あるいは 文献(13)に詳しく記載してあることから，ここでは省 略する。

$$
3 \pi \mu R U R e I_{L}=F_{D \infty, z}+3 \pi \mu R U \alpha R e I_{D, z}
$$
ここで,

$$
\begin{aligned}
& I_{L}=\frac{3}{4 \pi L^{* 2}} \int_{0}^{\infty} \int_{0}^{2 \pi} \frac{\chi+\rho}{\chi-\rho}\left(e^{-\rho}-e^{-\chi}\right)^{2} \rho d \rho d \phi \\
& \alpha I_{D, z}=\frac{3 \alpha}{4 \pi L^{* 2}} \int_{0}^{\infty} \int_{0}^{2 \pi} \frac{\rho^{2}}{i \cos \phi}\left\{\left(\frac{e^{-2 \rho}}{\rho}-\frac{e^{-2 \chi}}{\chi}\right)\right. \\
& \left.\quad+\frac{2\left(e^{-\rho}-e^{-\chi}\right)^{2}}{(\chi-\rho)}\right\} d \rho d \phi \cdots \cdots \cdots \cdots \cdots \cdots \cdots \cdots(5) \cdots \cdots \cdots \cdots(4)
\end{aligned}
$$

ただし， $\chi^{2}=\rho^{2}+i \rho L^{*} \cos \phi て ゙ あ り ， I_{L}$ はV Vasseur ら(8)の結果と同一であり，ID, は著者らが Vasseur $ら^{(8)}$ の方法を用いて得た滑り気泡に対する解と同様 にして求めたものである(13).

$R e \rightarrow 0, L^{*} \rightarrow 0$ の極限で $I_{L}, I_{D, z}$ の值および力の釣 合いはそれぞれ，

$$
I_{L}=\frac{3}{32}, I_{D, z}=\frac{9}{8 L^{*}}, F_{L}=6 \pi \mu R W\left(1+\frac{9}{8} \frac{R}{L}\right)
$$

となり，抵抗力については Stokes 近似に対する解と なる(15).

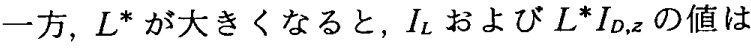
漸近解と異なり，式(4)および式(5)を数値的に積分

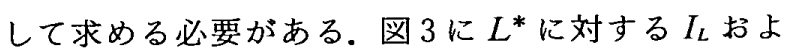
び $L^{*} I_{D, z}$ の值を示す. 図 3 中, 実線は式 $(4)$ を数値 積分した值，破線は式(5)を数值積分した値を表す。 図 3 より，L*が大きくなるにしたがい, $I_{L}$ と $L^{*} I_{D, z}$ の值がどちらも小さくなることがわかる. 特に, $L^{*}$ が 1 前後においてその変化が大きい.また, $L^{*} か ゙ 10$ 
を超えたあたりで壁の影響がほとんどなくなることが わかる、つまり, Re 数が小さくても距離が十分離れ れば, 壁の影梓を受けず, あるいは, 距離が近くても $R e$ 数が大きければ壁の影響を受けにくいのは共通し た傾向である．実際 $x$ 方向については，本実験の条件 $R e>0.9$ かつ $L^{*}>3$ において, 無限流体中の上昇速 度に対する減少は $3 \%$ 以下であり，壁の影響は軽微で あった。

実験結果からは，気泡径，上昇速度，気泡・壁面間 距離が測定され, $R e$ 数, $L^{*}$, 気泡・壁面間距離の時 間変化から計算される $z$ 方向速度 $W$ が評価される. したがって, 式(5)で $I_{D, z}$ を計算すれば, 式(3)より 近似的に揚力が計算できる゙(13). 奏際, Vasseur ら ${ }^{(8)} の$ 低 $R e$ 数領域における奏験によれば， $L^{*}$ が 1 以上の 領域，つまり十分壁から離れた領域において測定した 垂直方向の速度 $W$ は, $U R e I_{L} / 2$ とよく一致してい る.この結果を式 $(3) に$ 代入し, Re が小さいことを 考慮すれば右辺第 2 項は零となる。すなわち， $L^{*}$ が 1 以上の領域では壁から離れる際の抵抗力 $I_{D, z}$ は相対 的に小さいことがわかり，近似式として十分であるこ とが確かめられる.

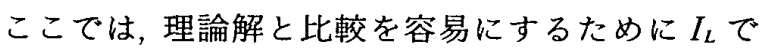
比較を行った。このとき，ILは以下のように計算され る.

$$
I_{L}=\frac{2 W}{U R e}\left\lfloor f(\operatorname{Re})+\frac{R}{L} L^{*} I_{D, z}\right\rfloor
$$

ここで， $I_{L}$ の不確かさについて触れておく．Ｉは $W, R e$ および $L / R$ の関数であり, それらの不確かさ は気泡径, 上昇速度の測定値, 気泡・壁面間距離おょ びその時間変化に起因する.この中で, 最も不確かさ の大きいものは $W$ であり，これは気泡・壁面間距離 の時間変化を三次関数でフィティングした後に，その 時間微分で評価しているからである，相関式に対する

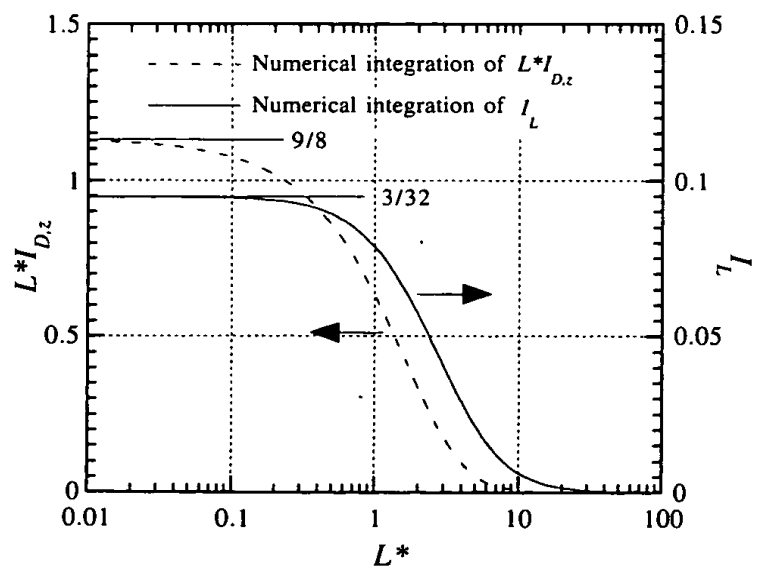

Fig. $3 L^{*} I_{D, z}$ and $I_{L, z}$ as a function of $L^{*}$
誤差解析(16) より，Wには 5〜15\%程度の不確かさが 含まれている。

気泡径の測定值の不確かさは，測定における人為的 な誤差としての画像 1 ピクセル分(約 $25 \mu \mathrm{m}$ )の不確か さを含む. 壁からの距離については, 壁の面が多少ほ けていることから，5ピクセル程度の不確かさを含む。 上昇速度の不確かさでは，気泡の重心位置測定での人 為的䛊差に起因するものが大きい.これは，気泡とカ メラの相対速度の誤差となることから, 気泡の上昇速 度が小さいほど上昇速度の不確かさが相対的に大きく なる.相対速度の不確かさは移動速度に関係なく約

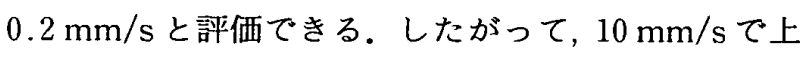
昇する場合には $2 \%, 100 \mathrm{~mm} / \mathrm{s}$ で上昇する場合には $0.2 \%$ が不確かさとなる。これらに動粘度の不確かさ を加えて誤差の伝ぱ(16) を考慮して誤差解析を行った。

\section{5. 結果と考察}

$5 \cdot 1 \quad 1<R e<5$ の場合における壁の影響 図 4 に $R e=0.9,2.5,5.0$ の場合における $L^{*}$ に対する $I_{L}$ を示す。図 4 中, 記号は実験結果で, 実線は式 (4)を 数值的に積分して求めた $I_{L, \text { analytical }}$ (以下 $I_{L, a}$ )である.

図 4 より, $R e=0.9$ の結果はほほ理論解と一致して いる.このことから, Re が小さい領域ではV Vasseur $ら^{(8)}$ の解と一致することがわかる. $R e=2.5$ の場合 には理論解よりも高い值となっている．滑り気泡の場 合においても, $R e=0.8$ の場合には理論解とほほ一致 するが, $R e=2.1$ では理論解よりも高い值となること から, 滑り気泡と同様の傾向を示す(13).

ところで, 本実験における気泡の抵抗係数は固体球 のものと一致しているが, Cuenot ら(4)によれば, 気 泡周りの近傍の流れ場は㛜密には固体球周りの流れ場 とは異なるという結果を得ている。しかしながら，本 実験結果が示すとおりその影響は小さく，固体球と同

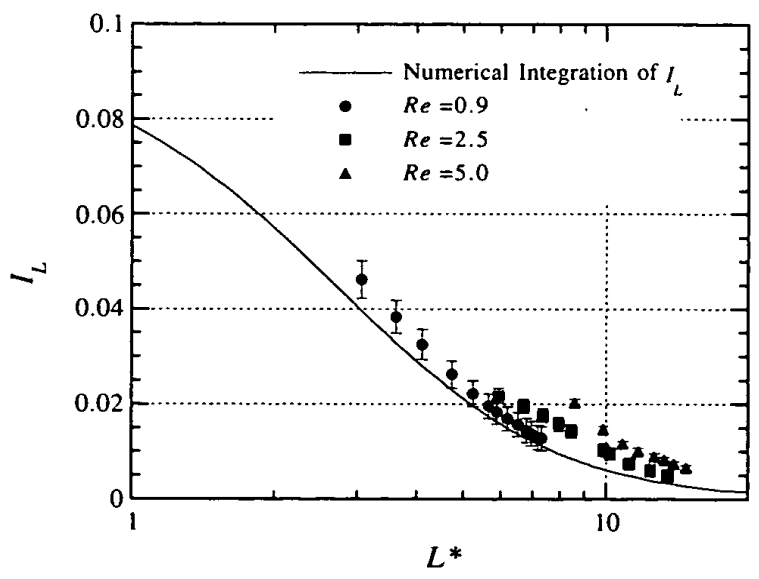

Fig. $4 I_{L}$ as a function of $L^{*}$ 
様に振る舞う水中の気泡が壁から受ける揚力は, 固体 球が受ける揚力と同じと考えてよい.

一方，Reが大きくなるにしたがい，理論解と実験 值は定性的には一致しているが, 揚力の值としては実 験值のほうが理論解よりも大きくなる．この傾向は， 滑り気泡と同様の結果である(13). Vasseur ら(8) の解 である式 (4)は, $R e$ 数が十分小さいことを仮定し, $O(R e)$ で求められた解である.したがって, Re>1 では解の適用外であり, 本実験結果との差として反映 されている.一方, $L^{*}$ が一定の場合において比較す ると, $R e$ 数が小さいほうが理論解に近いことがわか る.これは, $R e$ 数が小さくなるにしたがい, Vasseur $ら^{(8)}$ の解を導くための仮定である低 $R e$ 数という仮定 より厳密に満たすからである.

しかしながら，Re>2において理論解から揚力を推 測すること,すなわち揚力を $L^{*}$ の関数として記述す ることは難しい. つまり, 掦力は $R e$ 数と $L^{*}$ の関数 として記述しなくてはならない. $x$ 方向の抵抗力に関 しても同様のことがいえるが, $R e>1$ では無限流体中 での抵抗力に比較して壁の影響が相対的に小さい(本 実験条件では $3 \%$ 以内)ことから, 理論解が定性的に壁 の影響を評価できていれば，実験值と理論解には大き な差が生じない(12). しかし, 揚力の場合には理論解が 定量的に揚力を評価できなければ，実験値と理論解の 差が気泡の $z$ 方向の運動に直接的に影響を与え, 実験 值と理論解から計算される軌跡に大きな狂いが生じ る.したがって, 揚力を $R e$ 数と $L^{*}$ の関数として厳 密に記述する必要がでてくる. しかしながら,この結 果を得ることは容易でなく, 直接数值計算などと比較 する必要がある。

$5 \cdot 2 \quad 5<R e<20$ の場合における壁の影響 図 5 に $R e=7.7,14.2,17.7$ の場合における $L^{*} に$ 対する $I_{L}$ を示す. 図 5 中, 記号は実験結果で, 実線は $I_{L, a}$ で

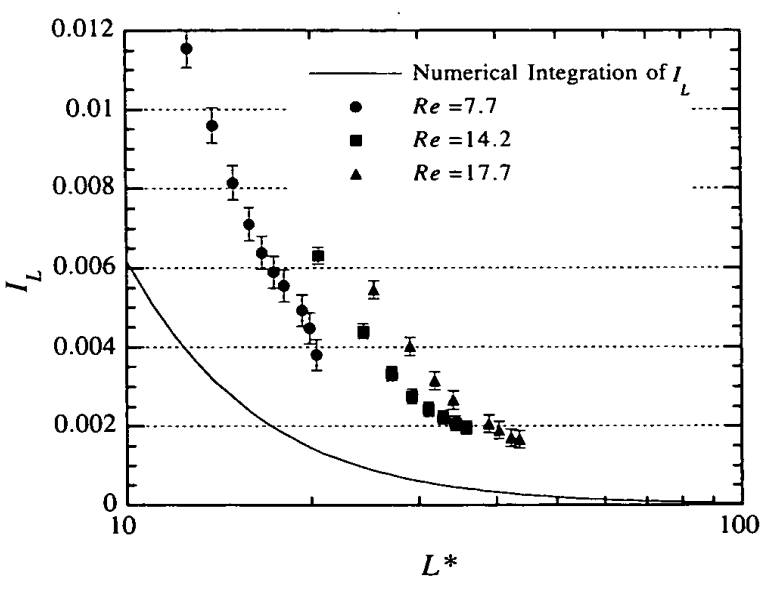

Fig. $5 I_{L}$ as a function of $L^{*}$
ある・

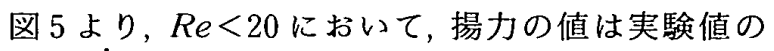
ほうが理論解よりも大きいこと， $L^{*}$ が一定の場合に おいては, $R e$ 数が小さいほうが理論解に近いことは, $R e>1$ の場合と同様であるが, $R e$ 数が大きくなるに したがいその違いは大きくなっている.したがって， この範囲の $R e$ 数の揚力の評価も, 直接数值計算など により求める必要がある.

すでに述べたように揚力係数 $I_{L}$ は $R e<1$ の範囲で は $L^{*}$ の関数として表せるが, $R e>1$ では $R e$ 数と $L^{*}$ あるいは, $R e$ 数と $L / R$ で表す必要がある. 図 6 にRe=0.9,2.5, 6.1, 14.2, 17.7の場合について, $L / R$ 数に対する $I_{L} / I_{L, a}$ を示す.

図 6 より $R e$ 数が大きくなるにしたがい, 比が大き くなることが確認できる，滑り気泡の場合と比較する と, $R e<20$ において, 理論解との比が $2 \sim 3$ 倍程度で あったが(13)，固体球の場合には 6 倍程度まで大きくな っている. Re<1ではともに理論解に一致すること から，この違いは $R e$ 数が大きくなることで顕在化し てきたものである.Vasseur ら ${ }^{(8)}$ の解の導出過程に よれば，気泡や粒子に働く力を，Oseen 近似を用いて 外部領域の流れ場から求める場合には，気泡および粒 子から受ける力の力点として取扱うことが可能であ る.つまり,この導出法では, Stokes 抵抗力の違い $4 \pi \mu U R$ と $6 \pi \mu U R$ に反映される以外に界面の境界条 件や粒子サイズを考慮する必要がない(17).

しかし, $R e>1$ における理論解との比は, 同じRe 数で比較すると, 固体球の場合のほうが大きくなって いる.これは, Stokes 抵抗力で規格化した滑り気泡 と固体球の無限流体中での抵抗力 $[$ そぞれ $h(R e)$ と $f(R e)]$ を比較すると, 固体球のほうが大きいことが 一つの理由としてあげられるが, 実際の值はその比以 上に異なっている。このことは，もはやこの領域では

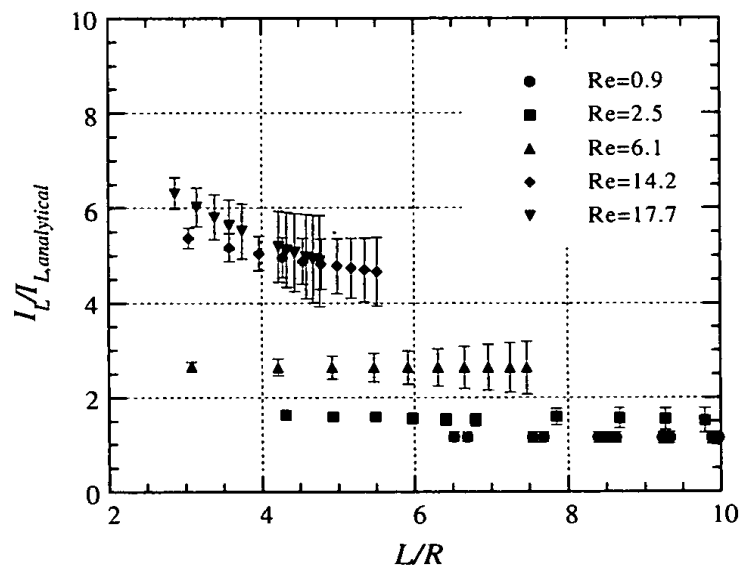

Fig. 6 Normalized $I_{L}$ as a function of $L / R$ 
粒子を力点とみなせず, 界面の境界条件や粒子サイズ の影帮を考慮する必要があることを示している.

そして，この影響により水中の気泡は壁の影艟をよ り高い $R e$ 数まで受けることとなっている.このこと は, 流れ場全体で考えると, 水中気泡のほうが界面で 滑り条件となる気泡に比べて，壁に寄りにくいという 結果につながる.

一方, $I_{L} / I_{L, a}$ に対する $L / R$ の依存性について考え ると, 本実験範囲では $I_{L} / I_{L, a}$ の值は $L / R$ の単調堿少 となっており，Re 数が大きくなるにしたがいそのこ う配が急になっている。これは, 界面近傍の洞度と壁 との干涉が，壁に近付くにしたがって強くなり，粒子 から受ける力を力点としてみなすことができなくなる ことが一つの理由として考えられる.また, 別の理由 として $R e$ 数が大きくなるにしたがい, 慣性の効果が より強く表れてくるとも考えられる. ポテンシャル理 論で考えると，流路が狭くなる壁側の圧力が下がり， 壁側に引っ張られる力が生じる. 境界条件は異なる が, 二つの粒子が並んで上昇する場合においては Re $=50$ において引力が働くという数値計算結果もあ る(18).ただし，本実験で引力が観察されたことはなか つたから, 複合的な要因であると考えるが, 前者の影 響が大きいため壁面近傍の壁面近傍で $I_{L} / I_{L, a}$ の值が 大きくなったと考えられる。

$5 \cdot 3 R e<20$ に対する揚力の推算式 これまで の議論から $R e<1$ ではV Vasseur ら ${ }^{(8)}$ の解が適用でき るが, Re>1における厳密解は直接数僧計算などから 求める必要があることがわかった，しかしながら，抗 力に比較して揚力は小さいことから，直接数值計算を 行うことも決して容易ではない，ここでは，㛜密性は やや落ちるが，実用性を重視することを考え，実験結 果を利用して簡便な推算式を求めることを試みる.

図 6 の結果および考察から, 界面近傍の渦度の干涉

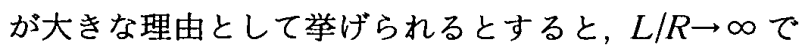
の $I_{L} / I_{L, a}$ の漸近值は力点として求めた $f(R e)$ に近付 くというのが比較的合理的な考え方である.これを考 虑に入れ, $I_{L} / I_{L, a}$ を $R e$ 数と $L / R$ の関数として相関 式にすると以下のようになる.

$$
g(R e)=\frac{I_{L}}{I_{L, a} f(R e)}=1+0.05 R e^{1.5}\left(\frac{R}{L}\right)^{0.1 R e^{0.63}}
$$

この式は $R e \rightarrow 0 て ゙, 1$ に漸近することから, 低 $R e$ 数 領域でも用いることができ，相関式と実験值の相対的 な違いの最大值は約 15\%である. また，この式の適用 範囲は $3<L / R<6$.であるが, $I_{L} / I_{L . a}$ の值は滑らかに 変化することから， $L / R$ が 10 程度まで使用しても軌

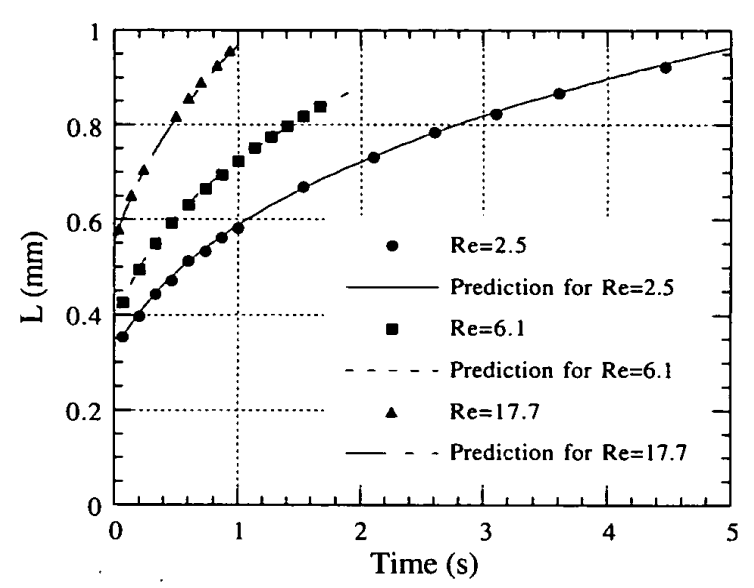

Fig. 7 Trajectory of bubbles

跡の計算において大きな狂いは生じないと考える.

この式を使うことにより, 式 (7)を変形して以下の ように $W$ を求めることができる.

$$
W=\frac{1}{2} \frac{U R e}{f(\operatorname{Re})+\frac{R}{L} L^{*} I_{D, z}} g(\operatorname{Re}) f(\operatorname{Re}) I_{L, a}
$$

したがって， $I_{L, a}$ を多項式などで近似すれば, 気泡径 および $L$ の情報だけで, 簡便に揚力および $W$ を求め ることができる. 図 3 に示される $I_{L, a}$ をフィティン グすると,

$$
\begin{aligned}
& I_{L, a}=0.0947-0.00147 L^{*} \\
& \quad-0.0239 L^{* 2}+0.00932 L^{* 3} \quad\left(0<L^{*}<1\right) \\
& I_{L, a}=0.109-0.0345 L^{*} \\
& +0.00470 L^{* 2}-3.05 \times 10^{-4} L^{* 3} \\
& +7.66 \times 10^{-6} L^{* 4} \quad\left(1 \leq L^{*}<10\right) \\
& I_{L, a}=0.83286 L^{*-2.1254} \quad\left(10 \leq L^{*}<100\right)
\end{aligned}
$$

となり, 式 (8) と式 (9)を合せて得られた $z$ 方向速度 を時間で積分することにより，気泡の履歴を計算する ことができる．図 7 に壁近傍を上昇する気泡の軌跡を 示す.シンボルは実験值を示し，実線，破線および一 点鎖線は推算式を積分して得られた結果である。ここ で, 推算式の積分では気泡径と壁からの初期位置のみ を与えて計算した。また， $x$ 方向の速度は壁の影響が ないものとして式 ( 2 )から計算を行い, $z$ 方向の壁の 影響は無視した. 図 7 よりどの場合においても十分精 度よく気泡の軌跡を計算でき，推算式を用いた簡便な 方法が十分適用可能であることがわかる.

\section{6. 結 論}

壁近傍を上昇する水中球形気泡の揚力を実験的に測 
定し，Vasseur ら (8) の結果を応用した揚力を評価する 式と比較した。その結果として以下の結論が得られ た.

（1） $L^{*}>3$ の条件においては，気泡の $x$ 方向上昇 速度の減少は $3 \%$ 以下であることから，壁の影響を考 慮しなくてもよい.一方， $z$ 方向では壁の存在による 揚力が発生し，壁から遠ざかる方向に移動する。

（2） $R e<1$ の条件では，理論解とよく一致し，固 体球のように振る舞う気泡は粒子と同様の揚力を得る ことが確認できた。 $R e>1$ では，理論解と実験值は定 性的には一致するが，揚力の值は実験值のほうが理論 解よりも大きくなる.また, Re 数が高くなるにした がい, 理論解との比は大きくなることから, 水中の気 泡の場合には壁の影響をより高い $R e$ 数まで受ける.

(3) 実験値と理論解の比を $R e$ 数と $L / R$ の関数 で表し, $R e<20$ かつ $3<L / R<6$ で適用可能な簡便な 揚力の評価式を提案し，その適用性を確認できた。

\section{文献}

(1) Duineveld, P.C., The Rise Velocity and Shape of Bubbles in Pure Water at High Reynolds Number, $J$. Fluid Mech., 292(1995), 325-332.

（2）寺門秀一・竹村文男・矢部彰, 水中の微小気泡の上昇举 動に及ぼす污れの影響，機論，67-656，B(2001)，955-960.

(3) Takemura, F. and Yabe, A., Rising Speed and Dissolu tion Rate of a Carbon Dioxide Bubble in Slightly Contaminated Water, J. Fluid Mech., 378(1999), 319334

(4) Cuenot, B., Magnaudet, J. and Spennato, B., The Effectsof Slightly Soluble Surfactants on the Flow around a Spherical Bubble, J. Fluid Mech., 339(1997), 25-53.
(5) Liao, Y. and McLaughlin, J. B., Bubble Motion in Aqueous Surfactant Solutions, J. Colloid Interface Sci., $224(2000), 297-310$

(6) Zhang, Y. and Finch, J. A., A Note on Single Bubble Motion in Surfactant Solutions, J. Fluid Mech., 429 (2001), 63-66.

( 7 ) Clift, R., Grace, J. R. and Weber, M. E., Bubbles, Drops and Particles, (1978), 30-141, Academic Press.

(8) Vasseur, P. and Cox, R. G., The Lateral Migration of Spherical Particles Sedimenting in a Stagnant Bounded Fluid, J. Fluid Mech., 80(1977), 561-591.

(9) Cox, R. G. and Hsu, S. K., The Lateral Migration of Solid Particles in a Laminar Flow Near a Plate, Int. J. Multiphase Flow, 3(1977), 201-222.

(10) McLaughlin, J. B., The Lift on a Small Sphere in WallBounded Linear Shear Flows, J. Fluid Mech., 246 (1993), 249-265.

(11) Cherukat, P. and McLaughlin, J., The Inertial Lift on a Rigid Sphere in a Linear Shear ${ }^{\circ}$ Flow Field Near a Flat wall, J. Fluid Mech., 263(1994), 1-18.

(12）竹村文男・高木周・松本洋一郎，壁面近傍における球形 ガス気泡の上昇速度，機論，66-648，B(2000)，2087-2094.

（13）竹村文男 - 高木周・松本洋一郎，壁面近傍を上昇する球 形ガス気泡に働く揚力，機論，66-649， B(2000)，23202326.

(14) Mei, R., Klausner, J. F. and Lawrence, C. J., A Note on the History Force on a Spherical Bubble at Finite Reynolds Number, Phys. Fluids, 6(1994), 418-420.

(15) Happel, J. and Brenner, H., Low Reynolds Number Hydrodynamics, (1963), 58-95, 286-331, Martinus Nijhoff Publishers.

(16) Benedict, R.P., ほか 5 名, Measurement Uncertainty, ANSI/ASMEPTC 19-1(1985), 1-55.

(17) Legendre, D. and Magnaudet, J., A Note on the Lift Force on a Spherical Bubble or Drop in a LowReynolds-Number Shear Flow, Phys. Fluids, 9(1997), 3572-3574.

(18) Kim, I., Elghobashi, S. and Sirignano, W. A., ThreeDimensional Flow over Two Spheres Placed Side by Side, J. Fluid. Mech., 246(1993), 465-488. 